\title{
Exploring Students' Experiences of Self- Regulated Learning during a Large Flipped Classroom Course in Teacher Education
}

\author{
Laura Hirsto ${ }^{1}$ \\ University of Helsinki/University of Eastern Finland \\ Helsinki, Finland/ Joensuu, Finland \\ https:/ / orcid.org/0000-0002-8963-3036 \\ Sanna Väisänen² \& Anni Arffman ${ }^{3}$ \\ University of Eastern Finland \\ Joensuu, Finland \\ 2https:/ / orcid.org/0000-0002-2981-912X \\ 3https:/ / orcid.org/0000-0003-4138-8374
}

\begin{abstract}
The aim of the study was to explore teacher students' experiences of self-regulated learning and the teaching-learning environment during a course following the Flipped Classroom approach. Theoretical perspectives include self-regulated learning and motivation, especially in terms of the fore-thought phase in which the students set goals for their studying and learning processes, and monitoring. Goals are approached, in addition to the immediate study context, from more general perspectives of teacher education preferences. This study consists of two parts. In Study 1, 156 Finnish teacher students responded in the initial survey and 144 students responded to the final survey. Altogether, 89 students responded to all the questionnaires. Study 2 includes interviews with six teacher students. The data were analyzed by using mixed methods including qualitative content analyses and various quantitative analyses. The results suggested that students come with various goals and interests in this kind of course and these are related to their experiences of the teaching-learning environment in various ways. Results also revealed that teacher students seem not to set clear goals for their studying on the course level, but broader teacher education preferences were related to their experiences of the teaching-learning environment. Also, student interest in the course seemed to be quite persistent as the original interest is related to the level of interest at the end of the FC course.
\end{abstract}

Keywords: Flipped Classroom; self-regulated learning; goal setting; sustainable development; teacher students

\footnotetext{
${ }^{1}$ Corresponding author: Laura Hirsto, laura.hirsto@uef.fi, laura.hirsto@helsinki.fi
} 


\section{Introduction}

Changing demands of working life requires universities to develop their teaching and learning environments in order to include digital pedagogical means and to support students' learning to respond to those changes. At the same time there are requirements to develop higher education learning environments towards more student-centered teaching and flexible learning environments which facilitate students' active role in the teaching and learning processes. There are various methods through which the students' active role in the teaching and learning situation can be facilitated, and through which a more student-centered learning environment achieved. The Flipped Classroom (FC) approach has gained increasing interest in recent years including the idea of emphasizing students' active role and inserting digital tools through which the flexibility of the learning environment and students' active role could be emphasized. Thus, it fits well with the progressive aims to provide university students student-centered and individualized learning opportunities (e.g., Toivola, 2016). However, FC also means that students need to change their behavior in the learning environment. In order for the FC approach to function, students need to prepare for the lectures by studying the assigned contents, which may be challenging if students are used to traditional lecture-based studying, where they usually do their individual work after more or less passively attending a lecture. To change that habit, students need to focus on regulating their own learning in a new way.

This study aims to understand university students' experiences of self-regulated learning during a Flipped Classroom course. Through two separate but related studies, this paper aims to gain a better understanding of the differing experiences of self-regulation processes and teaching-learning environment among teacher education students in a large lecture course which was designed by the principles of the Flipped Classroom.

\section{Theoretical perspectives}

The Flipped Classroom design includes generally the ideas that students are 1) provided online (lecture) material before class time, 2) engaged in discussion and collaborative group work during face-to-face sessions, and 3) engage in higherorder activities (e.g., Stonebraker, 2015). Empirically, FC is often a concrete step to change classroom dynamics: lectures are studied at home and the higher-order tasks, applications and group work will be done in the classroom. However, FC does not guarantee a learner-centered learning culture because it simply puts the focus on moving tasks in space and time, rather than on increasing engagement, autonomy or student centeredness (Abeysekera \& Dawson, 2015). Nevertheless, according to the findings of Mazur, Brown, and Jacobsen (2015), the Flipped Classroom approach that emphasizes collaborative learning, group work and accessibility can enable and support inquiry-based learning. Also, there seems to be support for the efficiency of the Flipped Classroom approach on student attainment and engagement (Enfield, 2013; Hibbard, Sung, \& Wells, 2016; Little, 2015; O’Flaherty \& Phillips, 2015).

There is some earlier research on self-regulation and FC, but according to $\mathrm{Ng}$ (2018) more research is needed in terms of varying contexts and lengths of 
learning through the FC approach. This study on one hand theoretically draws on Zimmerman's $(2000,2002)$ model of self-regulation. According to Zimmerman (2000), self-regulative learning includes three complementary phases. The forethought phase entails students' analyzing tasks, setting goals and planning how to reach those goals as well as self-motivational beliefs, such as intrinsic interest or value (Zimmerman, 2000, 2002). In the performance phase, students perform the task at hand, i.e. they use self-control strategies to finish a task, and during the self-reflection phase students assess their performance in the task, i.e. their success or failure (Zimmerman, 2000, 2002). The self-reflection phase includes self-reactions, such as satisfaction and positive affect towards ones' own performance (Zimmerman, 2002). From this perspective, especially the forethought phase has been given special attention, thus, what kind of goals students are seen to bring into the learning situations. These goals may be present on various levels, such as specific goals related to course content or their own learning during the course, as well as more general perspectives in relation to how the students see preferable teacher education.

Zimmerman's $(2000,2002)$ model has been complemented theoretically in this paper by perspectives of Ryan and Deci's (2000) self-determination theory (SDT). It describes further issues related to interest and extrinsic motivation, and the conditions which support intrinsic motivation, such as feelings of competence, autonomy and relatedness (Ryan \& Deci, 2000). Competence refers to the idea of the students' experience of feeling capable of, e.g., reaching their goals. Autonomy refers to the feeling of student being able to, e.g., affect their own learning processes and making choices. Finally, relatedness refers to the need of students to feel that they belong and that they are connected to other students.

Thus, to draw these perspectives together, self-regulation is seen as a process, which starts with preceding activities, including goal setting and experiences of self-efficacy and, further, self-regulation during learning activities includes strategic choices and self-assessment performed after work (Zimmerman, 2000). Ryan and Deci's (2000) self-determination theory includes perspectives of key contextual experiences that support intrinsic motivation. The FC approach usually utilizes individual study of pre-materials, which is applied, clarified and deepened during face-to-face time (e.g. Bergmann \& Sams, 2012; O’Flaherty \& Phillips, 2015).

There is evidence that self-regulative learning strategies may be significant for student achievement in FC learning environments (Sletten, 2015). Further, selfregulated learning is built on an assumption that students monitor their own learning consciously (Winne \& Hadwin, 2008). It is assumed in a Flipped Classroom that a student has responsibility for their own learning process (Kong, 2014) and that the FC approach creates more responsibility for one's own learning (O'Flaherty \& Phillips, 2015). Further, while students have more responsibility for their own learning, they also learn to better regulate it (Toivola \& Silfverberg, 2014). Also, through participation in interactive activities of face-to-face lessons, responsibility for one's own learning, as well as the ownership of one's own learning, proceed from a teacher to students (Pierce \& Fox, 2012). 
There is also already quite much existing research about the FC approach and students' experiences. For example, according to Wanner and Palmer (2015), university students experienced FC as flexible and they were able to search for their own ways of learning, however, students also thought that it is important to have a clear structure in a FC course. For example, students experience that being able to work and learn at their own pace and time is seen as useful (Gilboy, Heinerichs, \& Pazzaglia, 2015; Ng, 2016; Nouri, 2016). Also, Mortensen and Nicholson (2015) found that students experienced FC as enjoyable, whereas O'Flaherty and Phillips (2015) reported an increase in student satisfaction. However, there is evidence that students' approaches to learning affect their experiences of a teaching-learning environment (e.g., Parpala, Lindblom-Ylänne, Komulainen, Litmanen, \& Hirsto, 2012). Entwistle, McCune \& Hounsell (2002) have developed an approach through which general key elements of a learning environments that may support deep learning can be investigated. According to their measurement tool, they have identified six key elements within that: teaching aiming for understanding, staff enthusiasm and support, interest and relevance, support from other students, constructive feedback and constructive alignment. This approach by Entwistle et al. (2002) was taken into use in Study 1, and Study 2 used a more open approach to elicit students' actual experiences in relation to their self-regulation through interviews.

O'Flaherty et al. (2015) in their review of the studies investigating FC in higher education draw some interesting conclusions. According to them, it seems that decreasing the amount of subject matter in face-to-face sessions and engaging students, affect students' learning more than the sole preliminary material. Learning seems to be facilitated by the process of preparing for class and increasing interaction in face-to-face sessions. FC increases the proportion of learning that students are responsible for, since students are responsible for preparing for lessons and being more interactive during face-to-face sessions (O'Flaherty \& Phillips, 2015). Also, FC has modified the traditional roles of a teacher and students and increased the interaction between them (Pierce \& Fox, 2012) and a teacher's role is more of a coach than a teacher ( $\mathrm{O}^{\prime}$ Flaherty \& Phillips, 2015). Teaching sessions are utilized for individual and collaborative work, through which concepts are clarified and knowledge is contextualized by applying, analyzing, planning and producing (O'Flaherty et al., 2015).

Students think that attending active FC face-to-face lecture requires advanced preparation (Gross, Pietri, Anderson, Moyano-Camihort, \& Graham, 2015; Khanova, Roth, Rodgers, \& McLaughling, 2015). On the other hand, some of the students experience frustration and feelings of being overwhelmed because of the time required to sufficiently prepare for face-to-face sessions (Khanova et al., 2015). However, students seem to see that pre-class learning enables them to have more time to process new information and helps them to understand concepts and accomplish other learning objectives (Khanova et al., 2015).

Many times FC practices take place in classroom-size groups or small group tutoring, not through large or mass lectures. Also, FC practices seem to be more 
common in fields were the knowledge corpus builds in a cumulative manner, which helps in designing pre-assignments and learning material in terms of building on knowledge step by step. Here, we attempted to utilize the FC approach in a large lecture course in teacher education, which was part of advanced pedagogical studies.

Teacher students' self-regulation processes, in accordance with Zimmerman's (2000) model, are shown to utilize self-regulative learning that entails goal setting, task analysis as well as use of strategies and reflection on their learning (e.g. Saariaho, Pyhältö, Toom, Pietarinen, \& Soini, 2015). Previous studies on teacher students, for example, have reported analyzing the requirements for the course and set timetables for tasks at hand (Saariaho et al., 2015). Also, co-regulation was utilized, such as reflecting on learning with peers (Saariaho et al., 2015). In terms of the FC approach, it has been shown to create learning environments that support students to seek help, i.e. students seem to be more aware of their need for external help (Sun, Wu, Lee., 2017).

The goals students set for their learning may vary. For example, it has been shown that many students set goals for their learning that can be seen as performance goals and that students just want to pass a course (e.g. Sun et al., 2017). In collaborative courses, students may also reflect on their goals for the course in a similar manner as they reflect on their learning (see Saariaho et al., 2015).

The focus in this paper is on the various phases of the self-regulation process. In Study 1 the focus is on the role of the goal setting phase in the self-regulation process during a course which utilizes the FC approach in relation to students' experiences of the teaching-learning environment. Thus, a major focus is how and what kinds of goals teacher education students set and what kinds of interests they name in the beginning of the course, and how these are related to their experiences of the teaching-learning environment provided by the large lecture course which utilizes FC approach. Study 2 complements the perspectives in addition to goals, into perspectives of learning strategies and motoring of the process. In both studies students' experiences, e.g. about the extent of the teaching of the course aiming for understanding, experienced interest and relevance and constructive alignment as well as satisfaction, are approached as students' reflections on their learning.

The goals are approached here, on one hand, on the course level. Another viewpoint on the goals that students have is taken here from a more holistic teacher education perspective; how teacher students see the essential core of teacher education in building their own teachership. The theoretical and empirical framework acquired in this study for teacher education goals draws from Zeichner's (1983) classical study on different kinds of paradigms behind teacher education programs. Two of the paradigms, which Zeichner (1983) recognized, have quite a practical emphasis, namely, the Behavioristic paradigm and the Traditional-craft paradigm. In terms of teacher education, the teacher student is seen in the Behavioristic paradigm as a mere receiver of professional knowledge, and there are not many possibilities for the student to influence the contents of 
the syllabi. The Traditional-craft paradigm, on the other hand, perceives teacher education as a process of becoming a skilled craftsperson through learning from more experienced teachers. In the Personalistic approach in Zeichner's (1983) model, the developmental process of becoming a teacher is more important than specific teaching skills. The Inquiry-oriented paradigm, in turn, emphasizes the development of a research-oriented attitude towards teaching and teaching contexts and the focus is on the development of a critical and systematic research orientation. Zeichner's (1983) model was built through interviews of teacher educators. Hirsto (2016) has operationalized Zeichner's paradigms into a questionnaire, and it seems that these dimensions can also be found among teacher students through factor analysis.

\section{The aim of the study}

The study aims to gain a better understanding of the differing experiences of selfregulation processes and teaching-learning environment among teacher education students in a large lecture course, which was designed by the principles of the Flipped Classroom approach. The self-regulation process was approached, on one hand, especially from the viewpoint of goal setting at the beginning of the teacher education FC course (Study 1) and, on the other hand, through the elements which supported or hindered students' self-regulation of their learning processes during a FC course (Study 2). The specific research questions are:

1) How are teacher students' goals, interests and teacher education paradigm preferences towards learning at the beginning of a course, designed based on the Flipped Classroom approach, related to their experiences of the teaching-learning environment and their interest at the end of the course? (Study 1)

2) What kinds of experiences of the self-regulated learning process did the teacher education students have during a course carried out with a Flipped Classroom approach? (Study 2)

3) What are the key elements supporting and hindering teacher students' selfregulation processes during a course carried out using the Flipped Classroom approach? (Study 2)

\section{Method}

\section{Research context}

This study (both Study 1 and Study 2) was conducted in the Education for sustainable future 5 ECTS mass lecture course, which was a compulsory part of teacher education students' master's-level studies, more specifically, advanced studies. Extent of the course was five credits, which was divided into face-to-face sessions (20 hours) and independent work (105 hours, including project work). The structure of the course is presented in Figure 1, in which it is described how the Flipped Classroom approach was utilized during the course. The aim of this course was, for example, that participants can recognize her/his professional and educational role as a participant in society and as an educator for a sustainable future. Also, this course was part of the development project of learning 
environments carried out at a multidisciplinary research university in Finland. The study was conducted in three similar courses during three consecutive study years and in all three years the course design followed closely the similar Flipped Classroom approach. During the course, students were asked to get acquainted with and study various online materials on a digital learning platform in advance of every lecture. These online materials included, for example videos and articles. During the lectures, the issues studied before the face-to-face session were discussed and applied further through varying case-based methods.

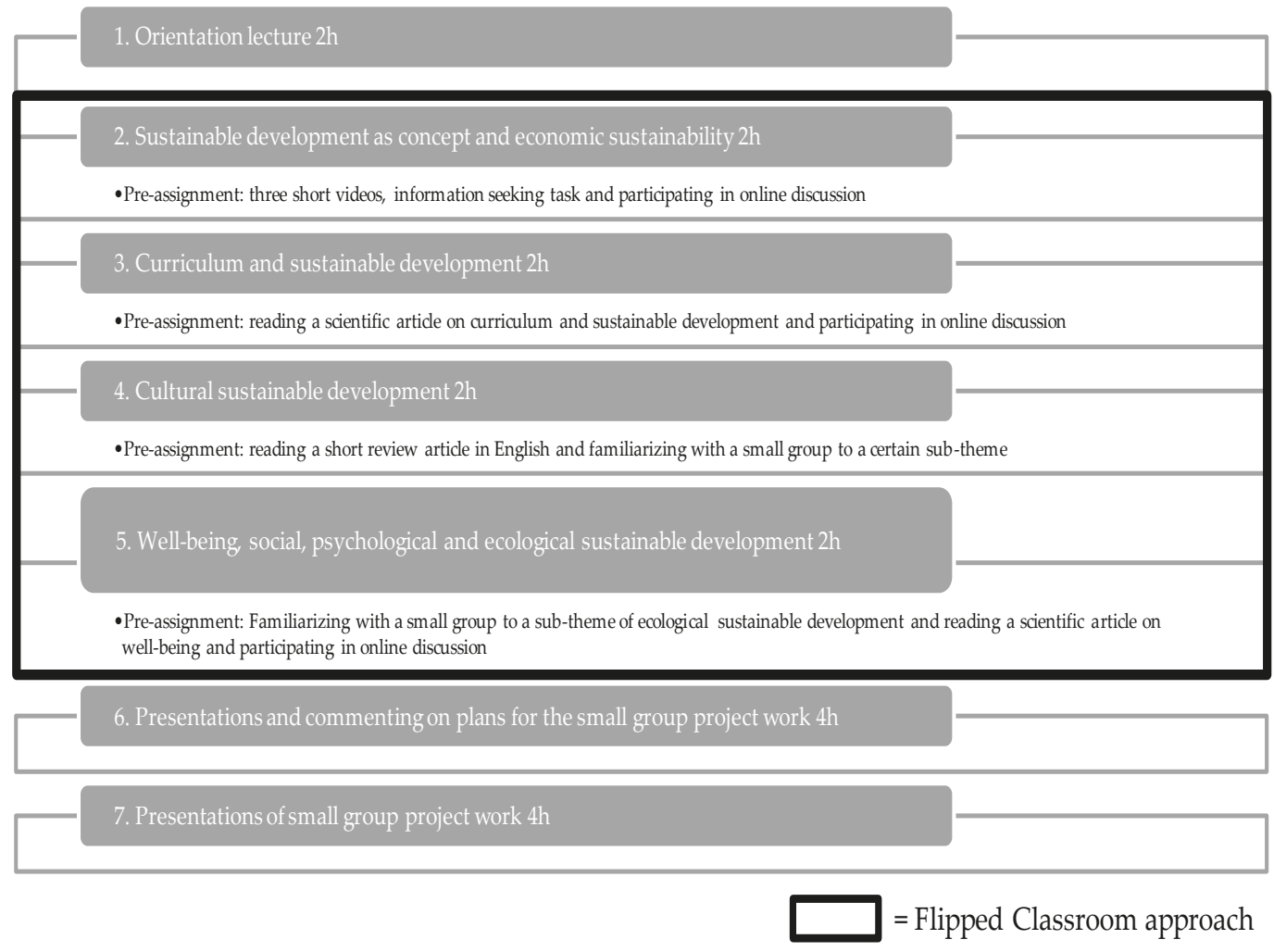

Figure 1: The structure of the course, Education for the Sustainable Future 5 ECTS

\section{Study 1}

\section{Participants}

The data for Study 1 was collected during the course so that in the beginning of the course students' general teacher education preferences, goals and interests were surveyed, and at the end of the course students' experiences of the teachinglearning environment provided by the course investigated. Students' were asked for informed consent and permission to connect answers from the different measurement points. Also, pairwise comparisons were used for the various analyses, therefore the number of respondents varies somewhat from analysis to analysis. The aim was to analyze the full data set, which was done separately for the different measurement points, to get a thorough perspective of all answers provided. However, as relations were investigated, the number of cases included was determined by the measurement point with pairwise comparisons. Altogether 156 primary and subject teacher students participated in the first questionnaire in the beginning of the study (women 78.8 \%; men $19.9 \%$; other 1.3 
$\%)$, and 144 students responded at the end of the course. As the data was collected through repeated questionnaires, 89 students responded to all questionnaires. A majority of the respondents in the beginning of the course $(71.3 \%)$ were $3^{\text {rd }}$ and $4^{\text {th }}$-year teacher students. $78.6 \%$ were primary teacher students, and $21.4 \%$ were subject teacher students in home economics $(6.5 \%)$ and arts and crafts $(14.4 \%)$ majoring in the educational sciences. The age range of the students was from 22 to 44 , and the median was 25 years. Of the students, $46 \%$ were between 22 to 24 years old. The division of gender and age groups is comparable to the general Finnish teacher education context.

The data was collected during the spring of 2016 and 2017. In general, $78 \%$ of the students were not familiar with the FC approach, and $22 \%$ had at least some previous knowledge. Participants were informed of the nature of the study, and that participation was on a voluntary basis. They were requested to complete a questionnaire during each lecture. It took between 5 to 15 minutes to complete the questionnaire. As the questionnaires were filled out during the class period, the response rates were high. Moreover, only a couple of students refused the use of their responses in the research project.

\section{Measures}

The measures included in this study are presented in Figure 2. In the beginning of the first lecture (T1), all students responded to a questionnaire, which included open-ended questions about their goals and interest towards the course, and quantitative items concerning their general teacher education paradigm preferences (Table 1, Likert 1-5) (Hirsto, 2016; see also Zeichner, 1983). Sum variables for teacher education paradigm preferences with example items, alphas and means are presented in Table 1.

\begin{tabular}{|l|l|}
\hline T1: & $\begin{array}{l}\text { T2: } \\
\text { - Background information } \\
\text { - Goals for the course } \\
\text { - Interests in the content } \\
\text { - Teacher education } \\
\text { paradigm preferences }\end{array}$ \\
\hline
\end{tabular}

Figure 2: Research design

At the end of the course (T2), students were asked about their general experiences of the course through the quantitative ETLQ questionnaire (see Table 4, Likert 15) (e.g., Entwistle, et al., 2002), as well as open-ended questions about their reflections on the variation of their interest level during the course and opinions about the Flipped Classroom in general. 
Table 1: Sum variables of teacher education paradigm preferences (cf. Hirsto, 2016)

\begin{tabular}{|c|c|c|c|c|}
\hline Sum variable & $\mathbf{\alpha}$ & Mean & St.dev. & Example item \\
\hline $\begin{array}{l}\text { the Traditional-craft } \\
\text { approach }\end{array}$ & .69 & 3.8 & .68 & $\begin{array}{l}\text { "Observing the work of } \\
\text { experienced teachers is the best } \\
\text { way to learn to be a teacher." }\end{array}$ \\
\hline $\begin{array}{l}\text { the Practical } \\
\text { approach }\end{array}$ & .63 & 4.6 & .45 & $\begin{array}{l}\text { "Practical training is the most } \\
\text { important factor in developing as a } \\
\text { teacher." }\end{array}$ \\
\hline $\begin{array}{l}\text { the Personalistic } \\
\text { approach }\end{array}$ & .71 & 4.2 & .73 & $\begin{array}{l}\text { "Teacher education should focus } \\
\text { especially on facilitating teacher } \\
\text { students to build their own strong } \\
\text { teacher identity." }\end{array}$ \\
\hline $\begin{array}{l}\text { the Inquiry-oriented } \\
\text { approach }\end{array}$ & .69 & 3.7 & .67 & $\begin{array}{l}\text { "I cannot see much use for } \\
\text { educational theories and research } \\
\text { in teacher training." (reversed) }\end{array}$ \\
\hline
\end{tabular}

The qualitative content analyses in Study 1 were conducted together with the first two authors, and the classifications were negotiated until a full agreement was reached. Qualitative content analyses were conducted separately for teacher students' responses to each of the following questionnaire items: 1) goals for the course, 2) interests concerning the theme of the course, 3) experienced variation of interest level and 4) experiences of the FC approach.

\section{Results of Study 1}

\section{Course goals and interests and their variation}

According to analysis, it seems that students had goals related to applying the contents of the course to teaching and their own teachership (see Table 2). Quite many student responses referred to an interest in deepening their own knowledge in the subject area. However, there were also some students whose major interest was to get the ECTS credits or just to finish the course.

Table 2: Students' goals for the course

\begin{tabular}{|c|c|c|c|}
\hline & Frequency & Percent & Example \\
\hline $\begin{array}{l}\text { Goals related to } \\
\text { teachership and } \\
\text { application of } \\
\text { contents }\end{array}$ & 67 & 54.0 & $\begin{array}{l}\text { "I want to learn and understand how the } \\
\text { principles of sustainable developed can be } \\
\text { applied in practice in a school environment } \\
\text { and teaching situations" }\end{array}$ \\
\hline $\begin{array}{l}\text { Goals related to } \\
\text { deepening the } \\
\text { contents and } \\
\text { understanding }\end{array}$ & 30 & 24.2 & $\begin{array}{l}\text { "I will learn to think about sustainable } \\
\text { development more broadly and from } \\
\text { multiple perspectives from the viewpoint of } \\
\text { education." }\end{array}$ \\
\hline Other goals & 27 & 21.8 & $\begin{array}{l}\text { "I came [to the course] with an open mind. I } \\
\text { don't know much about the theme, so not a } \\
\text { lot of expectations.", "I will pass this course } \\
\text { the best I can and will do all the } \\
\text { assignments well and on time." }\end{array}$ \\
\hline Total & 124 & 100.0 & \\
\hline
\end{tabular}


Analysis of the students' responses to the question about their interests based on the theme of the course produced five distinct categories (Table 3). The biggest category was 'Content interest' which consisted of descriptions related purely to the theme of the course. The second largest category 'Intermediate interest' included responses in which students referred to a general interest. 'Low interest', again, included responses in which the students did not have any specific interest in and had not found out anything about the theme of the course. Some students' interests focused on the content as well as on the pedagogical themes, and a small group of students also described an interest related to who they are in relation to sustainable development.

Table 3: Students' interests in the theme of the course

\begin{tabular}{|c|c|c|c|}
\hline & Frequency & Percent & Example \\
\hline Content Interest & 36 & 30.8 & $\begin{array}{l}\text { "Interesting themes that I hope to gain } \\
\text { perspectives on and put into practice, so } \\
\text { that it will not remain too theoretical." }\end{array}$ \\
\hline Low Interest & 28 & 23.9 & $\begin{array}{l}\text { "I have not really checked what this course } \\
\text { is about." }\end{array}$ \\
\hline Intermediate & 31 & 26.5 & "The theme [of the course] is quite \\
\hline Interest & & & $\begin{array}{l}\text { interesting, but it is difficult to say to what } \\
\text { extent the actual contents are interesting." }\end{array}$ \\
\hline ContentPeda & 13 & 11.1 & "The theme is really broad and interesting. \\
\hline Interest & & & $\begin{array}{l}\text { I'm sure it will be of use in personal life as } \\
\text { well as in a teacher's work. These aspects } \\
\text { facilitate my interest." }\end{array}$ \\
\hline Identity Interest & 9 & 7.7 & $\begin{array}{l}\text { "I'm interested, I'm on ecological person } \\
\text { and I try more and more to live in such a } \\
\text { way that does not burden the earth..." }\end{array}$ \\
\hline Total & 117 & 100.0 & \\
\hline
\end{tabular}

\section{Students' teacher education preferences}

Students' teacher education preferences were approached first through theoretical factors of the teacher education paradigms, and the sum variables were constructed based on those. To acquire the person-oriented picture of variation of how teacher education students perceived the teacher education preferences, a Kmeans cluster analysis was conducted. According to the analysis, three different student profiles based on their teacher education paradigm preferences were found (Figure 3). Research-based teacher identity (Series 1, n=38), Practical teacher orientation (Series 2, n=24) and Practical teacher identity (Series 3, n=66). $\mathrm{K}$-means cluster analysis was used, as it seeks groups within the data that are significantly different from each other. 


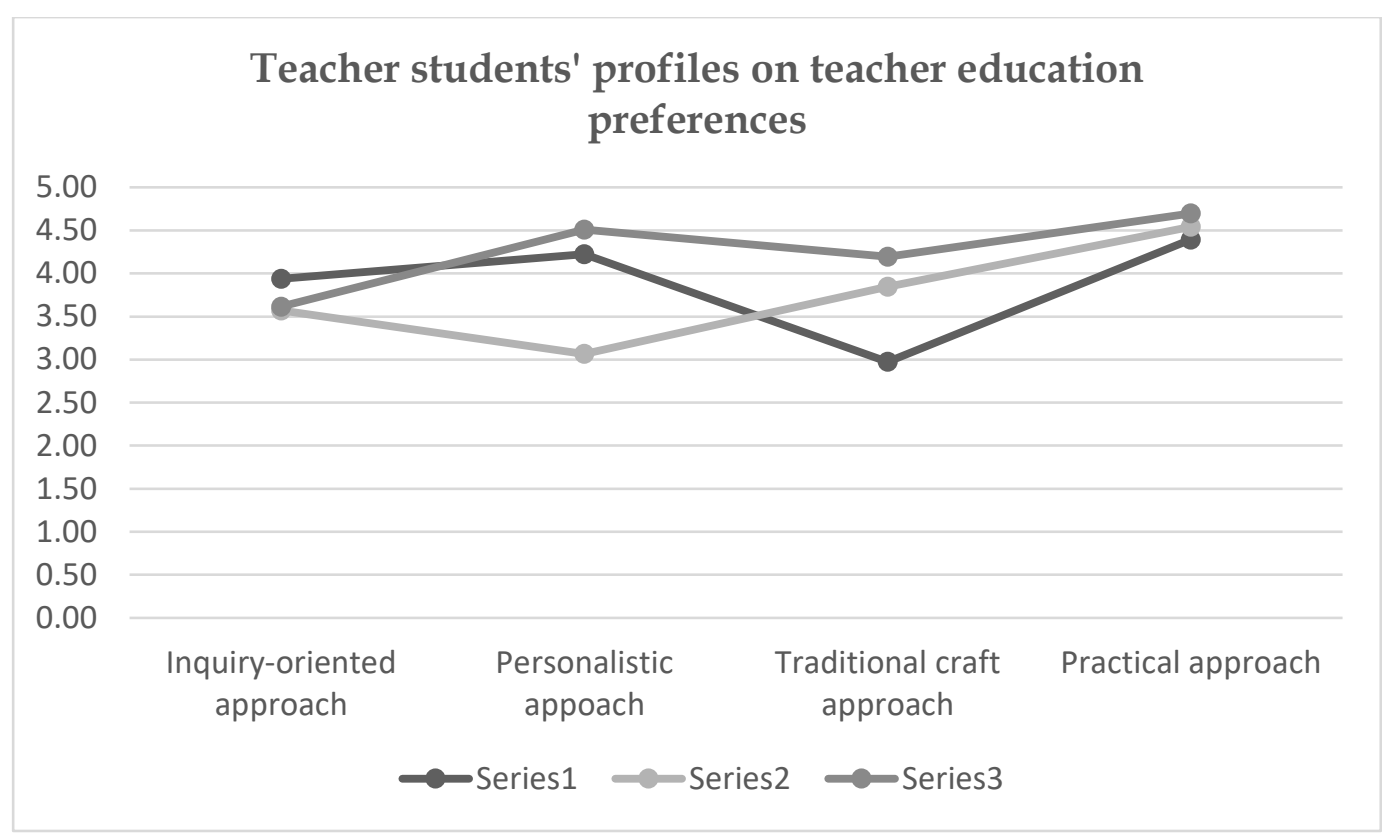

Figure 3: Teacher students' profiles on teacher education preferences

Students' experiences of the teaching-learning environment were surveyed at the end of the course. The reliabilities and means of ETLQ-questionnaire are reported in Table 4. The reliabilities of five sum variables were on an acceptable level, however, the sum variable of support from other students has low reliability. That final sum variable will be kept in the analyses as it is part of the ETLQ, and Study 2 will bring additional perspectives to that. Support from other students was also experienced quite highly (cf. Likert 1-5). Also, constructive alignment, teaching for understanding and interest and relevance, as well as staff enthusiasm and support, were on a quite good level. Students' experiences related to constructive feedback were on an intermediate level and the variation of responses was also quite large.

Table 4: Reliabilities and means of experiences of the teaching-learning environment (ETLQ) sum variables

\begin{tabular}{|c|c|c|c|c|c|}
\hline Sum variable & $\begin{array}{l}\mathrm{N} \text { of } \\
\text { Items }\end{array}$ & a & Mean & $\begin{array}{l}\text { St. } \\
\text { dev. }\end{array}$ & Example item \\
\hline $\begin{array}{l}\text { Teaching for } \\
\text { understanding }\end{array}$ & 4 & .71 & 3.4 & .61 & $\begin{array}{l}\text { "The teaching in this unit helped me to } \\
\text { think about the evidence underpinning } \\
\text { different views." }\end{array}$ \\
\hline $\begin{array}{l}\text { Constructive } \\
\text { alignment }\end{array}$ & 4 & .74 & 3.6 & .64 & $\begin{array}{l}\text { "What we were taught seemed to match } \\
\text { what we were supposed to learn." }\end{array}$ \\
\hline $\begin{array}{l}\text { Staff enthusiasm } \\
\text { and support }\end{array}$ & 2 & .70 & 3.3. & .76 & $\begin{array}{l}\text { "Staff tried to share their enthusiasm } \\
\text { about the subject with us." }\end{array}$ \\
\hline $\begin{array}{l}\text { Interest and } \\
\text { relevance }\end{array}$ & 3 & .77 & 3.4 & .69 & $\begin{array}{l}\text { "I found most of what I learned in this } \\
\text { course unit really interesting." }\end{array}$ \\
\hline $\begin{array}{l}\text { Constructive } \\
\text { feedback }\end{array}$ & 2 & .74 & 2.9 & .81 & $\begin{array}{l}\text { "The feedback given on my set work } \\
\text { helped to clarify things I hadn't fully } \\
\text { understood." }\end{array}$ \\
\hline $\begin{array}{l}\text { Support from } \\
\text { other students }\end{array}$ & 2 & .57 & 4.2 & .58 & $\begin{array}{l}\text { "Students supported each other and } \\
\text { tried to give help when it was needed." }\end{array}$ \\
\hline
\end{tabular}




\section{Students' reflections on the variation of their interest during the flipped classroom course}

At the end of the course, students were asked to reflect on their interest and motivation and how those varied during the duration of the course. Students' responses were classified into four categories (Table 5). The highest proportion of students (one third of the students) expressed that they had high or rising interest in relation to course duration. The second most common perspective was that students experienced varied interest levels during the course. Approximately one fifth of the students expressed that they had a low or decreasing interest with respect to course duration, and approximately one sixth of the students referred to their general interest, without reflecting on it further.

Table 5: Variations of interest during the FC course

\begin{tabular}{|c|c|c|c|}
\hline & Frequency & Percent & Examples \\
\hline $\begin{array}{l}\text { High or rising } \\
\text { interest }\end{array}$ & 38 & 33.9 & $\begin{array}{l}\text { "My interest remained throughout the course } \\
\text { and it was interesting to do teamwork. Teachers' } \\
\text { lectures also initiated more thorough thought.", } \\
\text { "I was not very motivated from the beginning, } \\
\text { but my motivation increased as the course } \\
\text { progressed and with more interesting topics." }\end{array}$ \\
\hline $\begin{array}{l}\text { Low or } \\
\text { decreasing } \\
\text { interest }\end{array}$ & 24 & 21.4 & $\begin{array}{l}\text { "The course took place during a time when there } \\
\text { were many other things to do. I did not always } \\
\text { have time to familiarize myself with the course } \\
\text { contents as well as I would have liked.", "At first } \\
\text { I was much more interested than at the end." }\end{array}$ \\
\hline $\begin{array}{l}\text { General } \\
\text { interest }\end{array}$ & 18 & 16.1 & $\begin{array}{l}\text { "I thought the topic was important, but not all } \\
\text { the specific goals of the course were fully } \\
\text { understood.", "Interesting course!" }\end{array}$ \\
\hline $\begin{array}{l}\text { Varying } \\
\text { interest }\end{array}$ & 32 & 28.6 & $\begin{array}{l}\text { "Well, my interest has been mixed, but mostly } \\
\text { due to issues from my everyday life.", “The } \\
\text { project work was very meaningful. A few } \\
\text { lectures were not interesting. Not every lecturer } \\
\text { can inspire students." }\end{array}$ \\
\hline
\end{tabular}

At the end of the course, students were also asked to evaluate their learning outcomes (Table 6). The largest number of students expressed that their knowledge had grown deeper or larger. A similar category describing the deepening and widening knowledge was named "Awareness of the dimensions grown." The expressions placed in this awareness category all referred to the various dimensions of the sustainable development which were discussed during the course quite thoroughly, as the deeper and larger knowledge category included statements referring to knowledge more broadly. Some of the students also referred to learning related to their pedagogical competence. If a student's response included these pedagogical perspectives, in addition to the deepening content knowledge, that student was placed in this category. However, there was also a group of students who thought that they had not really learned anything new during the course. 
Table 6: Students' reflection on their learning during the FC course

\begin{tabular}{|c|c|c|c|}
\hline & Frequency & Percent & Examples \\
\hline $\begin{array}{l}\text { Pedagogical } \\
\text { competence/ } \\
\text { competency }\end{array}$ & 14 & 12.7 & $\begin{array}{l}\text { "The course broadened my view of } \\
\text { sustainable development as a whole and } \\
\text { its sub-areas and integration into } \\
\text { education.", "I know the concept of } \\
\text { sustainable development and recycling, } \\
\text { for example. My understanding grew on } \\
\text { how I could relate it to teaching in } \\
\text { different ways." }\end{array}$ \\
\hline $\begin{array}{l}\text { Deeper and larger } \\
\text { knowledge }\end{array}$ & 50 & 45.5 & $\begin{array}{l}\text { "That sustainable development is not just } \\
\text { about recycling and sorting garbage." } \\
\text { "My views have become more diverse } \\
\text { and deepened. Indeed, sustainable } \\
\text { development had much broader } \\
\text { implications than I had thought." }\end{array}$ \\
\hline No change & 12 & 10.9 & $\begin{array}{l}\text { "Not much. It reminded me of its } \\
\text { importance!" “They [my conceptions] } \\
\text { haven't changed much. I have studied } \\
\text { these things before." }\end{array}$ \\
\hline $\begin{array}{l}\text { Awareness of the } \\
\text { dimensions grown }\end{array}$ & 34 & 30.9 & $\begin{array}{l}\text { "Dilated! } \rightarrow \text { different areas, I learned a } \\
\text { lot about different areas, all important." } \\
\text { "My perception was broadened: what } \\
\text { contents sustainable development } \\
\text { includes." }\end{array}$ \\
\hline
\end{tabular}

\begin{tabular}{lll}
\hline \hline Total & 110 & 100.0
\end{tabular}

Relations between goals, interests, teacher education preferences and students' experiences of the teaching-learning environment

Teacher students' teacher education preferences were related to their experience that the course had aimed at teaching for understanding $\left(\mathrm{F}=3.802, \mathrm{p}<.05, \mathrm{\eta}^{2}=.08\right.$, medium). The mean among students of the Research-based teacher identity group was highest, second highest was in the Practical teacher identity group and lowest for Practical teacher orientation group ( $x=3.6, x=3.3, x=3.2$, respectively).

The goals students mentioned at the beginning of the course did not seem to be significantly related to the interests they had in terms of the theme of the course. There were also no significant relations between the experiences of the teachinglearning environment at the end of the course and the explicated goals for the course in the beginning. The original interest in the beginning of the course was related to the experienced interest and relevance in the teaching-learning environment at the end of the course ( $\mathrm{F}=6.429, \mathrm{p}<.001, \mathrm{\eta}^{2}=.24$, large). Thus, according to the post hoc test (Scheffe), students reporting Content Interest in the beginning of the course evaluated their interest and course relevance significantly higher compared to students originally reporting low interest (mean difference $.73, \mathrm{p}<.01$ ) or intermediate interest (mean difference $.59, \mathrm{p}<.05$ ), and students with original ContentPeda interest reported higher interest and relevance compared to the original Low interest group (mean difference .79, $\mathrm{p}<.05$ ). 
An interesting perspective of teacher students' experiences during the FC course was that students who were familiar earlier with the Flipped Classroom approach more often thought that teaching aimed for understanding during this specific course $(\mathrm{t}(91)=2.335, \mathrm{p}<.05, d=.60$, intermediate). However, students' goals, interest or teacher education preferences were not significantly related to the students' reflections of their own learning at the end of the course or their evaluation of the teaching and learning environment.

The variations of interest teacher students experienced during the course were not significantly related to their original interests. However, there were certain significant relations between the descriptions of variation and students' experiences of the teaching learning environment at the end of the course (Table 7). In general, students with low or decreasing interest seemed to experience this FC course slightly more negatively. They have the lowest mean on all the dimensions of the ETLQ, even though the differences do not reach significance on all dimensions.

Table 7: Students' experiences of the teaching-learning environment in relation to variation of interest during the course

\begin{tabular}{lcccccccc}
\hline \hline & $\begin{array}{c}\text { High or } \\
\text { rising } \\
\text { interest }\end{array}$ & $\begin{array}{c}\text { Low or } \\
\text { decreasing } \\
\text { interest }\end{array}$ & $\begin{array}{c}\text { General } \\
\text { interest }\end{array}$ & $\begin{array}{c}\text { Varying } \\
\text { interest }\end{array}$ & $\mathbf{F}$ & $\mathbf{p}$ & $\mathbf{\eta}^{2}$ \\
\hline $\begin{array}{l}\text { Teaching for } \\
\text { understanding }\end{array}$ & $3.60 \mathrm{a}^{*}$ & $3.06 \mathrm{~b}$ & $3.49 \mathrm{ab}$ & $3.20 \mathrm{~b}$ & 5.251 & .002 & .13 \\
$\begin{array}{l}\text { Constructive } \\
\text { alignment }\end{array}$ & $3.60 \mathrm{a}$ & $3.31 \mathrm{a}$ & $3.76 \mathrm{a}$ & $3.68 \mathrm{a}$ & 2.168 & $\mathrm{~ns}$. & \\
$\begin{array}{l}\text { Staff enthusiasm } \\
\text { and support }\end{array}$ & $3.45 \mathrm{a}$ & $2.90 \mathrm{~b}$ & $3.67 \mathrm{a}$ & $3.13 \mathrm{ab}$ & 5.013 & .003 & .12 \\
$\begin{array}{l}\text { Interest and } \\
\text { relevance }\end{array}$ & $3.59 \mathrm{a}$ & $3.13 \mathrm{a}$ & $3.61 \mathrm{a}$ & $3.30 \mathrm{a}$ & 3.190 & .027 & .08 \\
$\begin{array}{l}\text { Constructive } \\
\text { feedback }\end{array}$ & $3.09 \mathrm{ab}$ & $2.54 \mathrm{a}$ & $3.39 \mathrm{~b}$ & $2.77 \mathrm{ab}$ & 5.179 & .002 & .13 \\
$\begin{array}{l}\text { Support from } \\
\text { other students }\end{array}$ & $4.12 \mathrm{a}$ & $4.04 \mathrm{a}$ & $4.19 \mathrm{a}$ & $4.33 \mathrm{a}$ & 1.322 & $\mathrm{~ns}$. & \\
\hline \hline
\end{tabular}

${ }^{*}$ means with same index-letter did not differ significantly according to post hoc test (Scheffe), $\mathrm{p}<.05$

\section{Teacher students' experiences of the Flipped Classroom approach}

At the end of the course, students were also asked about their experiences of the Flipped Classroom approach during the course (Table 8). Almost equal shares of the students (one fifth) experienced the FC approach as a really interesting working model and moderately interesting working model. Also, approximately one sixth of the students pointed out either of the two challenges in relation to the FC approach. One group of students experienced that the FC approach could have worked better if all the students would have done the pre-assignments which are the key ingredients of FC designs. Also, one third of the students experienced that it was difficult to apply and deepen one's knowledge during the lectures. This may relate to the challenge of not all students engaging in studying the contents beforehand as well as to the way that face-to-face sessions were organized in a large lecture hall with approximately 80 participants present at the same time. 
Thus, the pedagogical designs of the face-to-face sessions had to be based on group work, which the teachers could facilitate only to some extent. The category of 'other experiences' included a variety of neutral, unsure and partly negative answers, in which the students felt that other teaching models are better.

Table 8: Students' experiences of the FC approach

\begin{tabular}{|c|c|c|c|}
\hline & Frequency & Percent & Examples \\
\hline $\begin{array}{l}\text { Moderately } \\
\text { interesting }\end{array}$ & 22 & 21.4 & $\begin{array}{l}\text { "Flipped is motivating as long as it is applied } \\
\text { in the correct moderation. One is } \\
\text { institutionalized into FC quickly if there is } \\
\text { too much [of it]. On the other hand, there are } \\
\text { many kinds of flipped tasks. Note: different } \\
\text { methods.", "Good idea. I have not been } \\
\text { aware of it before." }\end{array}$ \\
\hline $\begin{array}{l}\text { Really interesting } \\
\text { and working } \\
\text { method }\end{array}$ & 21 & 20.4 & $\begin{array}{l}\text { "With the help of pre-material, one was able } \\
\text { to become familiarized with the topic of the } \\
\text { next lecture.", "I think this kind of learning } \\
\text { works. The course gives you direct access to } \\
\text { the essential issues." }\end{array}$ \\
\hline $\begin{array}{l}\text { Students' } \\
\text { engagement seen } \\
\text { as a challenge }\end{array}$ & 15 & 14.6 & $\begin{array}{l}\text { "It didn't work because not everyone did the } \\
\text { pre-assignments.", "It is quite functional as } \\
\text { long as all students are thoroughly familiar } \\
\text { with the pre-material." }\end{array}$ \\
\hline $\begin{array}{l}\text { Deepening } \\
\text { knowledge } \\
\text { during lectures } \\
\text { was a challenge }\end{array}$ & 14 & 13.6 & $\begin{array}{l}\text { "Good idea, but the course focused entirely } \\
\text { on self-study; teachers did not play a big role } \\
\text { in the lectures. I would have liked to have } \\
\text { more of the teachers' direct instruction on } \\
\text { the contents, because we were supposed to } \\
\text { have lectures.", "In my opinion, lectures } \\
\text { should have been used to deepen things, not } \\
\text { just to review homework. The same things } \\
\text { were repeated too much from the same } \\
\text { perspectives in the lectures." }\end{array}$ \\
\hline Other experiences & 31 & 30.0 & $\begin{array}{l}\text { "I remained to reflect on its [Flipped } \\
\text { Classroom approach] necessity. The same } \\
\text { things could have been covered in lectures.", } \\
\text { "Didn't inspire me. It might inspire me in a } \\
\text { different situation later." }\end{array}$ \\
\hline Total & 103 & 100.0 & \\
\hline
\end{tabular}

\section{Conclusions on Study 1}

The goals teacher students set for the course were not significantly related to their interests in the contents of the course. Also, it seems that the goals students set are not related to the experiences of the teaching environment. Teacher students' perspectives on how teacher education should be arranged in general, however, seems to be related to the extent to which they experience that teaching in the FC course aims at understanding. Also, students' interests seem to be quite stable as their interests in the beginning of the course are significantly related to the experienced interest and relevance at the end of the course. However, stronger relations were found in the way students described their interest and its variation 
during the course and various perspectives of experiences of the teachinglearning environment.

Thus, it seems that teacher students' goals are not relevant for their experiences of the teaching-learning environment, and that their interest seemed to be quite stable during the course. Students with content or content and pedagogical interest in the beginning of the course experienced more interest and relevance at the end of the course. Also, students with low or decreasing interest during the course experienced the teaching-learning more negatively from various perspectives. It was also noticed that students who had previous experience with the FC approach more often experienced that the teaching of this kind of course aimed at facilitating students' understanding. The question remains whether the FC approach courses provide without special attention adequate support for students' goal setting and engagement during the course. This Study 1 focused specifically on the first phase of Zimmerman's (2002) approach to the selfregulation process, which includes goal setting and orientation of the course as well as perspectives on interest. According to the perspectives found in students' reflections on their experiences of the FC approach, some students experienced that there were challenges in engaging all the students in the way of studying in the FC approach, especially in terms of all the students finishing the set assignments on time. Also, another challenge was pointed out related to the form of the face-to-face session being in the format of a large lecture session with about 80 students, which was seen to have led to an experience of not being able to deepen student knowledge during the session. Of course, these perspectives may be related.

Study 1 has shown some interesting perspectives of the students' experiences of the FC approach of instruction used in a large lecture course in teacher education, and the relations between the first phase of the self-regulation process (thus, goals and original interests) and students' experiences of the FC course. However, it still remains unclear how these students manage their self-regulation and monitoring during the course, and the specific elements that are important in supporting students' self-regulation. These are investigated in Study 2, which is based on the third author's Master's thesis (Arffman, 2018).

\section{Study 2}

\section{Participants and the Interviews}

The data for Study 2 was collected with semi-structured interviews (e.g., Kvale, 2007) during the spring term of 2018. Altogether, six teacher education students participated in interviews. At the beginning of the course, Education for a sustainable future, willingness to participate in interviews was requested in writing, i.e. participation was on a voluntary basis. Interviews took place in the end of the course and students reflected on the whole course period. The criterion for participating in the interview was that a student had taken part in all the activities during the course, since there was also a possibility to carry out the course tasks individually and independently, without participating in the course sessions. 
The interview frame was divided into three divisions based on Zimmerman's $(2000,2002)$ theory on self-regulation, i.e. before the course, during the course and after the course. Accordingly, the interview questions included perspectives on students' self-regulation experiences, such as attitudes on and planning of personal learning, monitoring of studying strategies, and self-reflection. Before the actual interviews, one pilot interview was conducted. This interview is included in the analyzed interviews. The interviews were audio-recorded digitally and transcribed into text files. Altogether, there were 225 minutes of interview data.

Study 2 utilized a qualitative approach to explore teacher students' views of their self-regulation during the large FC course. A combined data-driven and theoryguided content analysis was used as the analysis method (Bengtsson, 2016; Elo \& Kyngäs, 2008). In the first phase of analysis, Zimmerman's (2000) and Ryan and Deci's (2000) theories were utilized and applied and, further, the data was separated into meaningful expressions. After that, the found expressions were reduced into shorter descriptions, and those that described the same ideas were formulated into sub-categories. Sub-categories were combined into categories on the grounds of similarities. Categories were compressed into five themes, such as students' attitudes towards the course and intrinsic interest. The theoretical background was also considered while formulating themes. Qualitative analyses for Study 2 were conducted primarily by the third author and discussed together with the first author.

\section{Results of Study 2}

The data analysis produced five themes depicting the students' experiences of self-regulation (see Figure 3). Students' attitudes towards the course and their intrinsic interest were divided into two opposite views, of which positive aspects, i.e. strong intrinsic interest and positive attitudes towards learning, were prevalent. For example, a teacher student expressed that "This course was highly anticipated and was, for that reason, very meaningful." Interviewed students had open and positive attitudes towards the course. Students also reported to be motivated and they had a desire to learn something new. Interest in studies was aroused not only by the theme of the course but also the freedom to choose one's own theme for the group work that could be associated with experiencing autonomy. However, not all the students had intrinsic interest in the course or the Flipped Classroom pre-materials. In this case, their goal for the course was only to pass it and, hence, their personal meanings for the course were minor. For example: "Graduating, and that you get the credit points. That was maybe the most important aspect for me." Further, students saw that they had needed readiness and studying skills to accomplish completing the course. Some of the students also emphasized the importance of peers for their sense of being able to manage in the course. 


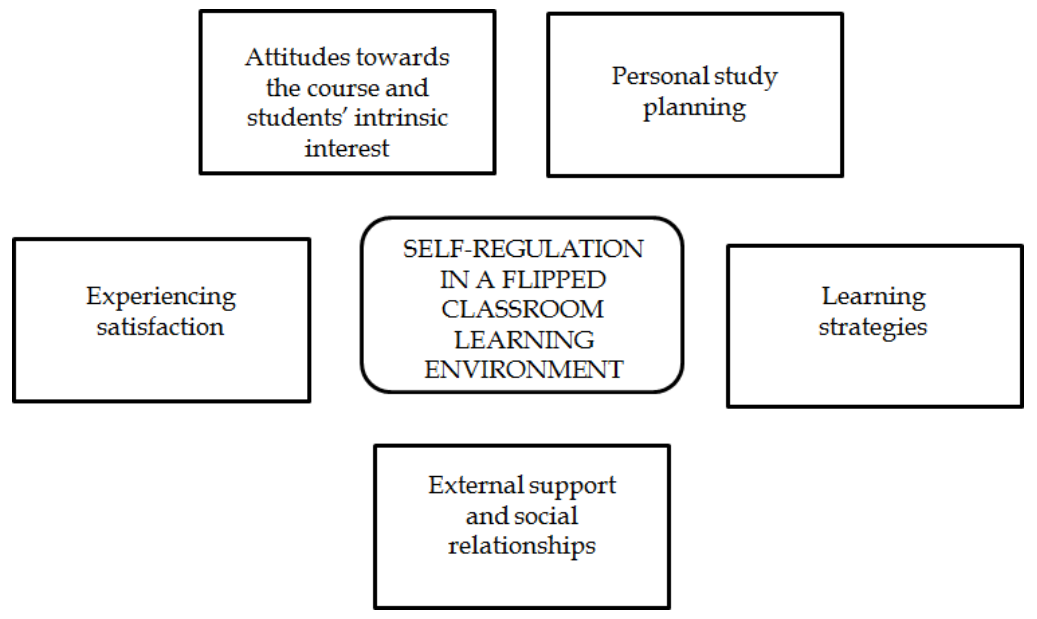

Figure 3: Themes of teacher students' experiences of self-regulation

Students' learning plans showed that, in general, personal goals were not set in a particularly conscious manner. Yet, some of the students reported the increase in knowledge as their outcome expectations, as one student saw that "...not that much in terms of expectations, but well, my knowledge of sustainable education was pretty basic when the course started, so I hoped to get more familiar with the information and content of that subject." Also, goal setting included satisfaction with one's own performance, success in group work and an increase in one's own understanding and knowledge. A student, for example, explained that "To gain more knowledge and something substantial and practical for working life."

Further, some of the students also mentioned strategic planning as their forethought activity. This strategic planning included, for example, a decision to participate in the face-to-face classes, planning timetables in groups as well as completing a course phase by phase. Also, students saw the importance of carrying out studies by taking care of required tasks. Taking part in and doing tasks were seen not only as important for one's own studying, but also for successful completion of the course.

Students' strategies for learning included self-instruction, especially in terms of time management and planning. Students, for example, may have set themselves a deadline, during which they aimed to perform a task. Also, imagery is among the strategies included in learning. For example, students' interest in a certain topic that was covered might have encouraged them to study it more. However, there were also tasks that raised imageries that did not positively affect students' performance, such as an English language article in the pre-materials. On the other hand, imagery about the necessity of pre-materials encouraged students to study. Attention focusing as a part of teacher students' learning strategies was not mentioned widely; however, some of the students did use selecting knowledge and recognizing concentration that can be seen as central aspects of regulating one's own actions. A teacher student may, for example, pay attention to things that are meaningful and right for their learning. They may, also, observe their own actions and concentration during a face-to-face class. A teacher student brought forth that "[By concentrating on] What things are those kinds of things that I do not need to remember. Maybe through that, I was able to hear the right things." 
Task strategies for one's own learning and managing demands were vast. It was common for teacher students to plan their own time management and action. They, for example, took care of doing tasks by writing them down and by planning a specific time for doing those tasks. Especially, pre-materials were worked on independently at home. However, students' own knowledge was also increased in interaction with peer students and by utilizing answers and reflections done by other students in the digital Moodle-platform. For example, "I read other students' texts from Moodle and took a look at what they had thought and made my own reflection based on that." Concrete studying methods for learning, which teacher students reported were written and repetitive methods which at the same time would facilitate understanding. They, for example, mentioned taking notes and reading and watching videos several times. It was also found that there was not that much conscious self-observation. Also, results showed that teacher students did not consciously evaluate their activities during the course. On the other hand, some of the students did recognize that they had experienced that their own actions and learning were not as productive as it could have been.

Students also reported the meaning of support and social relationships for their learning and self-regulation. Peer support and the sense of relatedness were shown to increase positive experiences and motivation towards the course (cf. Ryan \& Deci, 2000). Peers were, for example, sources of knowledge through conversations. Also, support for students' own learning was experienced through clear arrangements during the course. Face-to-face learning was experienced as meaningful for one's own learning. Those supported especially learning such content knowledge that could have remained poorly understood if studied only independently. Face-to-face lectures also supported the group work as those were experienced as possibilities to meet group members and to have discussions. There were also motivational aspects of face-to-face lectures: "I think that [without the face-to-face lectures] I may have worked less; that somehow those contact times maybe motivated me to also do the pre-material." Teacher students wanted to study prematerials so that they were prepared for topics of the face-to-face sessions, which may express their self-regulation towards their own learning and that they saw the meaning of preparing for their learning.

In addition, the members of a student's own group increased positive experiences during a course and friends were seen as supportive during lectures. Peer support and sharing the same studying experiences motivated students. Peers also helped generating new ideas and were helpful in memorizing things related to a course, such as pre-materials. Also, teachers were seen as having a positive influence on a course experience. Positive features were, for example, flexibility, opportunity to ask, reliability and human touch. The teacher was experienced as a factor increasing motivation in the course.

Teacher students also reported experiences of satisfaction towards the course. Students experienced satisfaction due to, for example, the autonomy the course enabled (cf. Ryan \& Deci, 2000). The possibility for autonomy was experienced in various ways to complete the course work as well as to plan and do group work. Students experienced that they had possibilities to have an effect on and freedom to choose towards own learning. For example: "Maybe also, why the course left so 
good feeling, was that it was from the very beginning that there were alternatives in ways you could accomplish the course work." Positive experiences were also generated by opportunities to choose the topic of group work on which to focus more deeply. Teacher students were also satisfied with the clarity and organization of the course as well as being informed about coursework timetables. Students reported that the way the course was arranged motivated them. There were only few teacher students who reported that they had good studying skills and that studying contents was easy. One of the students experienced his/her own competence as inadequate to carry out one of the tasks. In all, the course generated both positive and negative feelings and was seen as interesting, useful and memorable. Many of the students were satisfied with their own learning and one student even described having had a flow experience. Conversely, some of the students had a feeling that they did not understand, or had negative experiences due to their own attitude or because the course demanded a large amount of time. Also, some pre-materials resulted in frustration, irritation and stress on the part of students for either being quite challenging or because of the demands for new study habits with advance preparation for lectures.

The course also achieved small changes in teacher students' actions. They saw that the course differed from traditional studying, specifically in that one had to go to the face-to-face session with pre-acquired knowledge. Students experienced that they had to take responsibility for their own learning, but that lectures were needed for the understanding of things. Further, regarding the importance of the course, some of the students thought that a course was less important and only a compulsory part of studies. On the other hand, some of the students experienced it as very significant, especially in the content point of view: "Yes, it was significant. I hope that the materials can be shared because those were eye-opening and interesting. I think that particularly out of all the pedagogical studies this was the most useful course." The evaluation of one's own actions came up specifically with respect to satisfaction and examination of one's own feelings. However, the self-reflection on learning was partially incomplete among teacher students. This may be in connection to weakly set personal learning goals at the beginning of the course.

\section{Conclusions on Study 2}

Typical for teacher students was an intrinsic interest in and positive attitudes towards the course. Results also showed that students had not set clear objectives for their learning, which would have provided a means to better support their self-regulation during the course. This may have had an influence on teacher students' ability to evaluate their own learning at the end of the course. Also, previous studies have shown that many students set goals for their learning that can be seen as performance goals, as opposed to learning goals, and that students just want to pass the course (e.g. Sun et al., 2017). Furthermore, some students had goals to increase their knowledge as an outcome expectation.

Teacher students reported several strategies for their learning during a course. Some had utilized strategic planning as a forethought activity at the beginning of the course. Further, during the course, students' strategies for learning included self-instruction, especially in terms of time management and planning. Students, 
for example, may have set themselves a deadline, during which they aimed at to perform a task. Further, there were imageries that supported or hindered their learning and regulation of their own actions. Students reported to have worked on pre-materials mostly independently but also by getting familiar with peer students' ideas about the theme at hand via the Moodle platform. Also, previous research has shown that students see the importance of pre-materials for active participation and learning in a FC (Gross et al., 2015).

Results showed that the teacher students had mostly positive experiences towards the course compatible with the FC approach. Students were, for example, satisfied with the course. Also, O'Flaherty and Phillips (2015) reported an increase in students' satisfaction in FC courses. Further, results indicated that especially social relationships, i.e. peers and teachers, strongly affected the experiences of studies and contributed to self-regulation of learning. Especially peers were significant for most of the students during the whole course, i.e. going through the pre-materials, interaction during face-to-face time and doing group work. This seems to be connected with the experience of relatedness in supporting regulation and motivation, in comparison to Ryan \& Deci (2000). Also, teachers were seen to support teacher students' learning process. Teachers had created the kind of atmosphere that had a great impact on the positive experiences regarding the course. Also, previous research has detected that the Flipped Classroom has increased interaction between a teacher and students (Pierce \& Fox, 2012) and that it seems that the teacher's role is more of a coach than a teacher $\left(\mathrm{O}^{\prime}\right.$ Flaherty \& Phillips, 2015).

Teacher students also reported negative experiences, and that those arose mainly through pre-materials. Pre-materials were, for some students, experienced as challenging or frustrating, which was also detected by Khanova et al. (2015), who saw that some of the students experienced frustration and feelings of being overwhelmed because of the time required to sufficiently prepare for to face-toface sessions. Further, negative emotions may have led to giving up or performing below a student's typical level. Further, it may be argued that in these situations, a teacher student's competence has been inadequate and that may have had an effect on regulating their own action and motivation (cf. Ryan \& Deci, 2000).

\section{General discussion}

This paper investigated teacher students' experiences of self-regulation during a large Flipped Classroom course. The results of both Study 1 and Study 2 indicate that teacher students did not set explicit learning objectives for the course. However, the goals may play an important role in their experiences of the teaching-learning environment, as teacher students' more general preferences of teacher education were related to the students' experiences concerning the course on aiming for understanding. There is perhaps evidence also that students need time to adjust to this new way of learning, as those students who had previous experience with the FC approach more often experienced teaching related to this FC course as aiming for understanding compared to those who did not have previous experience with FC. This perspective of students' need to adjust to this new way of learning becomes explicit also in the students' qualitative answers on 
their experiences of the FC, as part of the students identified students' engagement in, for example, completing the pre-assignments.

In terms of the results of Study 2, teacher students seemed to utilize all the cyclical phases of self-regulation (see Figure 4), i.e. forethought, performance/volitional control and self-reflection as a part of their learning in the course performed in the flipped classroom environment (see Zimmerman, 2000, 2002). However, not all the dimensions were applied in a consistently wide and conscious way. Not all the teacher students come to the course in question with a clear picture about the course and goals set for their own learning. Especially, the reflection phase of the learning process did not come up despite experiences of satisfaction regarding the course. It may be proposed that the lack of intentionally setting goals at the beginning of the course and lack of deeper reflections at the end of the course may hinder self-regulation and, hence, meaningful learning processes. Accordingly, there seems to be a need for finding means for improving both personal goal setting and reflections on one's own learning in Flipped Classroom learning environments.

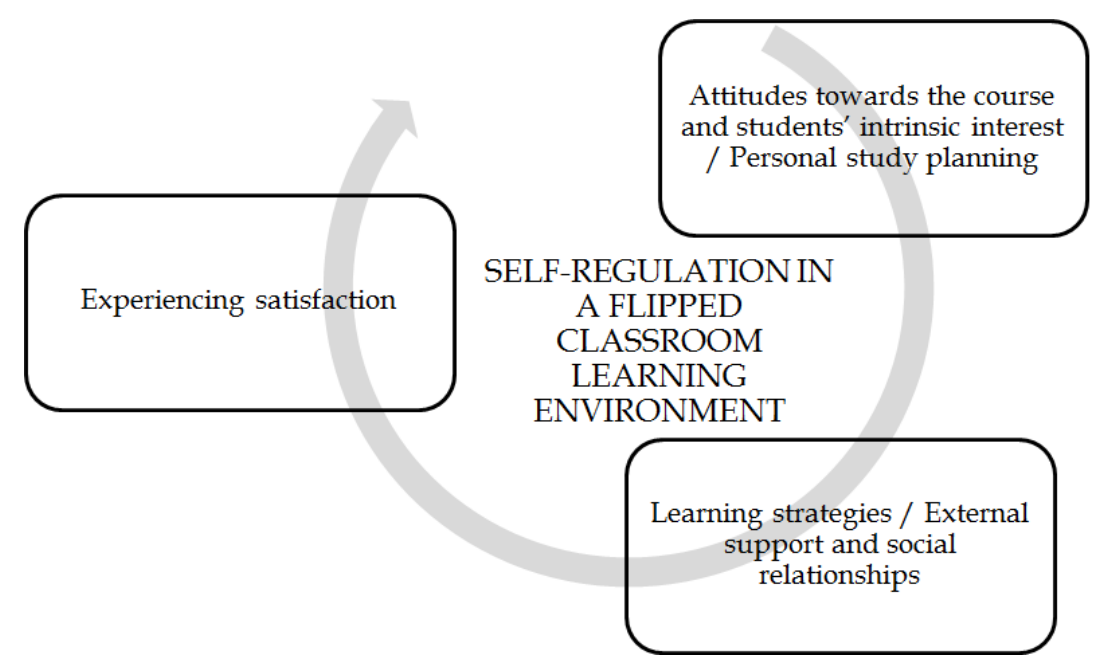

Figure 4: Key elements of the teacher students' experience of self-regulated learning during a Flipped Classroom course

It has been suggested that self-regulative learning strategies have significance for students' achievement in a Flipped Classroom (Sletten, 2015). These study findings showed that teacher students had various strategies for their learning, such as planning their use of time, getting familiar with pre-materials and doing group work. This was also supported by previous research suggesting that teacher students are shown to set timetables for tasks at hand (see Saariaho et al., 2015). During the course, social relationships with peers were perceived as meaningful for teacher students' learning as, for example, peers were sources of knowledge and provided a sense of relatedness that increased motivation towards a course. Furthermore, peers shared new ideas. Also, previous research suggests the meaning of co-regulation for teacher students' learning (Saariaho et al., 2015) and a sense of relatedness for motivation (Ryan \& Deci, 2000). The Flipped classroom has been shown to create learning environments that support students 
to seek help (Sun et al., 2017), it emphasizes collaborative learning and group work (Mazur et al., 2015). In accordance, teacher students' learning strategies during the course, such as preparing for face-to-face lessons and forming social relationships and co-regulation during a course, supported teacher students' selfregulation processes in the Flipped Classroom learning environment. Further, previous research has suggested that when students have more responsibility for their own learning, they also learn to better regulate it (Toivola \& Silfverberg, 2014).

Further, the course also created a sense of competence and autonomy (cf. Ryan \& Deci, 2000) for teacher students that increased teacher students' satisfaction towards the course and learning. This may be seen as one meaningful element supporting teacher students self-regulated learning processes. However, not all of the students had a sense of sufficient competence to carry out tasks needed to complete a course.

The challenge for the university is to better support students to guide them to consciously set goals for their own learning in a course from the beginning of studies so that they are also able to reflect on their own learning at the end of a course. The Flipped Classroom requires students to regulate their own learning, i.e. to self-regulate, but also to co-regulate and to take responsibility for their own learning to be successful in it. From the theoretical viewpoint, goals are important on the course level, however, also more general perspectives on the studies may have significant effects on students' study progress and success, such as personal goals (e.g., Litmanen, Hirsto, \& Lonka, 2010) or career choice certainty (e.g., Hirsto, 2012; Ketonen, Haarala-Muhonen, Hirsto, Hänninen, Wähälä, \& Lonka, 2016).

\section{Methodological reflections and directions for future research}

There are limitations that should be taken into account when generalizing the results of the present study. For example, this survey was carried out in one Finnish university, in a studying context that may vary notably in comparison to others in different countries. Further, not all the scales (e.g. teacher education paradigm preferences) have been validated in other teacher education systems outside of Finland. Also, the scales require further refinement to improve their reliabilities. The reliability of the measures could be increased for example by constructing additional items for the scales. There were only six interviews and that should also be noted while reflecting on the potential limitations of the transferability of the results of this study. Also, countries differ in their teacher education programs, so details of the findings may not be relevant in all parts of other contexts.

In further studies, it is important to deepen the understanding of processes of selfregulation in the Flipped Classroom environment. For example, exploring the ideas of students that have been studying longer via principles of the Flipped Classroom may bring new and deeper knowledge about the key elements of selfregulation it such contexts. 


\section{Acknowledgements}

Publishing this paper was partly supported by funding from the Finnish Ministry of Education's DigiPeda Flipped learning project [Grant no. OKM/199/523/2016] and TyöPeda project [Grant no. OKM/280/523/2017].

\section{References}

Abeysekera, L., \& Dawson, P. (2015). Motivation and cognitive load in the flipped classroom: definition, rationale and a call for research. Higher Education Research E Development, 34(1), 1-14, doi:10.1080/07294360.2014.934336.

Arffman, A. (2018). Kasvatustieteen opiskelijoiden kokemuksia itseohjautuvuudesta käänteistä opetusta toteuttavalta opintojaksolta [Experiences on self-regulation among students of educational science participating in a study unit using a Flipped Classroom approach] (Master's thesis, School of Applied Educational Science and Teacher Education, University of Eastern Finland). Retrieved from: http:/ / urn.fi/ urn:nbn:fi:uef-20181417

Bengtsson, M. (2016). How to plan and perform a qualitative study using content analysis. NursingPlus Open, 2, 8-14. doi:10.1016/j.npls.2016.01.001

Bergmann, J., \& Sams, A. (2012). Flip your classroom: Reach every student in every class every day. International Society for Technology in Education.

Elo, S., \& Kyngäs, H. (2008). The qualitative content analysis process. Journal of Advanced Nursing, 62(1), 107-115. doi:10.1111/j.1365-2648.2007.04569.x

Enfield, J. (2013). Looking at the impact of the flipped classroom model of instruction on undergraduate multimedia students at CSUN. TechTrends, 57(6), 14-27.

Entwistle, N., McCune, V., \& Hounsell, J. (2002). Approaches to studying and perceptions of university teaching-learning environments: Concepts, measures and preliminary findings. (Occasional Reports no. 1). University of Edinburgh, Durham and Coventry, ETL project.

Gilboy, M. B., Heinerichs, S., \& Pazzaglia, G. (2015). Enhancing student engagement using the flipped classroom. Journal of Nutrition Education and Behavior, 47(1), 109-114. doi:10.1016/j.neb.2014.08.008

Gross, D., Pietri, E. S., Anderson, G., Moyano-Camihort, K., \& Graham, M. J. (2015). Increased preclass preparation underlies student outcome improvement in the flipped classroom. CBE - Life Sciences Education, 14(4), ar36. doi:10.1187/cbe.1502-0040

Hibbard, L., Sung, S., \& Wells, B. (2016). Examining the effectiveness of a semi-self-paced flipped learning format in a college general chemistry sequence. Journal of Chemistry Education, 93, 24-30. doi: 10.1021/acs.jchemed.5b00592

Hirsto, L. (2012). Certainty of career choice at the beginning of university studies general strategies and attributions in achievement situations, and career motives. Studies for the Learning Society 2(2-3), 35-45. doi:10.2478/v10240-012$0005-2$

Hirsto, L. (2016, August). Teacher students' perspectives to teacher education approaches and the teacher as a researcher. Paper presented at the 4th International Symposium on New Issues in Teacher Education 2016, Savonlinna, Finland.

Ketonen, E., Haarala-Muhonen, A., Hirsto, L., Hänninen, J.J., Wähälä, K., \& Lonka, K. (2016). Am I in the right place? Academic engagement and study success during the first years at university. Learning and Individual Differences 51, 141-148. doi:10.1016/j.lindif.2016.08.017

Khanova, J., Roth, M. T., Rodgers, J. E., \& McLaughlin, J. E. (2015). Student experiences across multiple flipped courses in a single curriculum. Medical Education, 49(10), 1038-1048. doi:10.1111/medu.12807 
Kong, S. (2014). Developing in information literacy and critical thinking skills through domain knowledge learning in digital classrooms: An experience of practicing flipped classroom strategy. Computers and Education, 78, 160-173.

Kvale, S. (2007). Doing interviews. Los Angeles, California: SAGE.

Litmanen, T., Hirsto, L., \& Lonka, K. (2010). Personal goals and academic achievement among theology students. Studies in Higher Education, 35(2), 195-208. doi:10.1080/03075070902995205

Little, C. (2015). The flipped classroom in further education: literature review and case study. Research in Post-Compulsory Education, 20(3), 265-279. doi:10.1080/13596748.2015.1063260

Mazur, A. D, Brown, B., \& Jacobsen, M. (2015). Learning designs using flipped classroom instruction. Canadian Journal of Learning and Technology, 42(2), 1-26.

Mortensen, C. J., \& Nicholson, A. M. (2015). The flipped classroom stimulates greater learning and is a modern 21st century approach to teaching today's undergraduates. Journal of Animal Science, 93(7), 3722-3731. doi:10.2527/jas.20159087

Ng, E. M. W. (2016). The Flipped Classroom: Two Learning Modes that Foster Two Learning Outcomes. Issues in Informing Science \& Information Technology, 13, 1523.

$\mathrm{Ng}$, E. M. W. (2018). Integrating self-regulation principles with flipped classroom pedagogy for first year university students. Computers \& Education 126, 65-74. https://doi.org/10.1016/j.compedu.2018.07.002

Nouri, J. (2016). The flipped classroom: for active, effective and increased learningespecially for low achievers. International Journal of Educational Technology in Higher Education, 13, 33. doi:10.1186/s41239-016-0032-z

O'Flaherty, J., \& Phillips, G. (2015). The use of flipped classrooms in higher education: A scoping review. Internet and Higher Education 25, 85-95. doi:10.1016/j.iheduc.2016.02.002

O'Flaherty, J., Phillips, C., Karanicolas, S., Snelling, C., \& Winning, T. (2015). The use of flipped classrooms in higher education: A scoping review: Corrigendum. The Internet and Higher Education, 27, 90. doi:10.1016/j.iheduc.2015.05.001

Parpala, A., Lindblom-Ylänne, S., Komulainen, E., Litmanen, T., \& Hirsto, L. (2010) Students' approaches to learning and their experiences of the teaching-learning environment in different disciplines. British Journal of Educational Psychology 80, 269-282. doi:10.1348/000709909X476946

Pierce, R., \& Fox, J. (2012). Vodcasts and active-learning exercises in a "flipped classroom" model of a renal pharmacotherapy module. American Journal of Pharmaceutical Education, 76(10), 196.

Ryan, R., \& Deci, E. (2000). Self-determination theory and the facilitation of intrinsic motivation, social development, and well-being. American Psychologist, 55(1), 6878.

Saariaho, E., Pyhältö, K., Toom, A., Pietarinen, J., \& Soini, T. (2015). Student teachers' self- and co-regulation of learning during teacher education. Learning: Research and Practice, 2(1), 44-63 doi:10.1080/23735082.2015.1081395

Sletten, S. R. (2015). Investigating self-regulated learning strategies in the flipped classroom. In D. Rutledge \& D. Slykhuis (Eds.), Proceedings of 26th International Conference of Society for Information Technology \& Teacher Education (pp. 497-501). Waynesville, NC: Association for the Advancement of Computing in Education (AACE).

Stonebraker, I. (2015). Flipping the business information literacy classroom: Redesign, implementation, and assessment of a case study. Journal of Business $\mathcal{E}$ Finance Librarianship, 20(4), 283-301. doi:10.1080/08963568.2015.1072893 
Sun, J. C. Y., Wu, Y. T., \& Lee, W. I. (2017). The effect of the flipped classroom approach to OpenCourseWare instruction on students' self-regulation. British Journal of Educational Technology, 48(3), 713-729. doi:10.1111/bjet.12444

Toivola, M. K. (2016). Flipped learning - Why teachers flip and what are their worries? Experiences of teaching with Mathematics, Sciences and Technology, 2(1), 237-250.

Toivola, M., \& Silfverberg, H. (2014). Flipped learning-approach in mathematics teaching - A theoretic point of view. In P. Hästö \& H. Silfverberg (Eds.), Matematiikan ja luonnontieteiden opetuksen tutkimusseuran tutkimuspäivät 2014 [National Symposium of Finnish Mathematics and Science Education Research Association 2014] (pp. 93-102). Retrieved from: http://www.protsv.fi/mlseura/julkaisut/malu_2014FINAL.pdf

Wanner, T., \& Palmer, E. (2015). Personalising learning: Exploring student and teacher perceptions about flexible learning and assessment in a flipped university course. Computers and Education 88, 354-368. doi:10.1016/j.compedu.2015.07.008

Winne P., \& Hadwin, A. (2008). The weave of motivation and self-regulated learning. In D. H. Schunk \& B. J. Zimmerman (Eds.), Motivation and self-regulated learning. Theory, Research, and Applications (pp. 294-304). New York: Routledge.

Zeichner, K. (1983). Alternative Paradigms of Teacher Education. Journal of Teacher Education, 34, 3-9. doi:10.1177/002248718303400302

Zimmerman, B. J. (2000). Attaining self-regulation: A social cognitive perspective. In M. Boekaerts, P. Pintrich, \& M. Zeidner (Eds.). Handbook of self-regulation (pp. 13-39). San Diego, CA: Academic Press.

Zimmerman, B. J. (2002). Becoming a self-regulated learner: An overview. Theory into Practice, 41, 64-79. doi:19.1207/s15430421tip4102_2

\section{Biographies}

\section{Laura Hirsto}

Laura Hirsto (PhD, Educational psychology) is a research director and had been appointed to a professorship in the School of Applied Educational Science and Teacher Education at the UEF, and she is a senior lecturer in university pedagogy at the Higher Education Development Center at the University of Helsinki. Her research interests lie in the studying, learning and motivational processes of higher education students, teacher training, and the research-based development of teaching and learning environments (including $\mathrm{FC} / \mathrm{L}$ approaches) in various contexts. She is also a trained teacher with experience in both comprehensive and higher education.

\section{Sanna Väisänen}

Sanna Väisänen (PhD), School of Applied Educational Science and Teacher Education, University of Eastern Finland, Finland. Dr. Väisänen is a project researcher. Her research interests are in student teachers' study well-being, flipped classroom model and higher education students' worklife skills.

\section{Anni Arffman}

M. Ed. Anni Arffman is a qualified practicing teacher, who conducted a master's thesis under the supervision of Laura Hirsto. Study 2 in this paper is based on Arffman's master's thesis. 